\title{
QUANDO A RELIGIÃO FICA PERTO DA POLÍTICA: O CASO DOS CANDIDATOS APOIADOS PELO CATOLICISMO CARISMÁTICO NAS ELEIÇŌES DE 2014 NO BRASIL
}

\author{
Carlos Eduardo Pinto Procópio ${ }^{1}$
}

\begin{abstract}
Resumo: Este trabalho procura analisar a relação entre catolicismo carismático e política nas eleições proporcionais de 2014. Seu foco são as candidaturas de Padre Afonso (PV) e Flavinho (PSB), que receberam apoio de setores da Renovação Carismática Católica e da Comunidade Canção Nova na região do Vale do Paraíba/SP/BRA. Apesar de terem recebido apoio religioso, o que este trabalho demonstra é que ao lado dos elementos da religiāo, essas candidaturas acionaram elementos da política. Na medida em que atuavam sobre esses dois elementos da vida social, essas candidaturas fabricavam-se num movimento multiposicional. Nesse sentido, tanto a ampliação da retórica eleitoral para além dos vínculos originais quanto a justificação dessa ampliação ganham importância. Assim, antes que uma metamorfose da religião em política ou da política em religião, o que se passa é uma tentativa de articulação entre ambas. Nessa articulação, as tensões emergem forçando ressignificaçōes e rearranjos na maneira de conduzir a campanha política, levando os candidatos a movimentarem-se sobre um amplo campo de possibilidades.
\end{abstract}

Palavras-chave: Catolicismo carismático; Eleiçōes 2014; Multiposicional.

Abstract: This paper analyzes the relationship between Charismatic Catholicism and politics in the proportional elections of 2014. It focuses on two candidates: Father Alfonso (PV) and Flavinho (PSB), which received support from sectors of the Catholic Charismatic Renewal and the Canção Nova Community in the Valley of Paraíba/SP/BRA. Despite having received religious support, what this study shows is that beside the elements of religion, these candidates triggered elements of politics. While these two elements acted on the social life, these applications were manufactured in a moving multi-positional. Thus, both the expansion of the campaign rhetoric beyond the original bonds and the justification for this

1 Professor no Instituto Federal de São Paulo. Contato: procopiocso@yahoo.com.br

Debates do NER, Porto Alegre, ANo I6, N. 27, P. I99-232, JAN./Jun. 2015 
expansion gain importance. Therefore, it is not a metamorphosis of religion in politics or politics in religion what is happening, but an attempt to articulate both. In this articulation, tensions emerge forcing reinterpretation and rearrangements in the way of conducting political campaign, leading the candidates to move on a wide field of possibilities.

Keywords: Charismatic Catholicism; Elections of 2014; Multi-Positional

\section{INTRODUÇÃO: O QUE DIZEM AS CIÊNCIAS SOCIAIS SOBRE AÇÃ̇O POLÍTICA DOS CARISMÁTICOS CATÓLICOS}

A produção socioantropológica sobre carismáticos e política é muito incipiente, ainda mais se comparada ao número de estudos sobre a inserção política de grupos evangélicos (protestantes e pentecostais) ou, até mesmo, com estudos sobre grupos católicos tradicionais e progressistas. Tal fato deve-se mais ao desinteresse pelo tema do que pela ausência de participação política dos carismáticos. Isso é até certo ponto justificável, sobretudo quando compara-se a participação política dos carismáticos com a grande intensidade da presença evangélica na arena política, a partir da última metade da década de 1980 (Batista, 2009), e o forte engajamento de setores ditos progressistas da Igreja Católica nas lutas políticas dos anos 1970 e 1980 (Mainwaring, 1989). Contudo, quando se olha de perto para aquilo que carismáticos faziam nesse ínterim, a participação deste segmento diante da realidade política estaria presente desde a fundação de suas bases a partir de 1968, ano de seu aparecimento nos Estados Unidos. Stephen Hunt (2008) traz, na sua revisão dos estudos que encontrou sobre carismáticos no contexto estadunidense dos anos 1970/80, uma contribuição bastante significativa para essa discussão. O mesmo se dá com a pesquisa de Pedro Ribeiro de Oliveira (1978) sobre o Brasil que, apesar de ter concluído (apressadamente, acredito) que os carismáticos não são afeitos para a ação política, apresenta dados que permitem imaginar, ao contrário, uma predisposição para a prática política nesse segmento.

Debates do NER, Porto Alegre, ANo I6, N. 27, P. I99-232, JAN./Jun. 2015 
Hunt (2008) menciona que, no caso estadunidense, os estudos dos anos 1970/80 apontavam que os carismáticos não eram, desde o início, antagônicos, mas ambíguos em relação à ação política. Conforme esses estudos, esse segmento "[...] nem era substancialmente tradicionalista ou progressista, nem substancialmente liberal ou conservador" (Hunt, 2008, p. 31). De acordo com algumas pesquisas da época, segundo Hunt afirma (2008), a posição dos carismáticos era radical, se comparada à dos demais católicos, apesar de se colocarem mais à direita no geral. Outras análises, de acordo com Hunt (2008), apontavam que o fator classista tenderia a levar os carismáticos para uma posição mais à esquerda, pois eram detentores de um padrão de vida e escolar acima da média americana. Além disso, outros estudos sinalizavam que os carismáticos eram os responsáveis pela adequação do catolicismo à vida religiosa americana, na medida em que traziam, para dentro da instituição romana, uma ideia de individualização da religião e de uma cultura mais liberal (Hunt, 2008).

Ribeiro de Oliveira (1978), no que tange à realidade brasileira, deixa entrever que, apesar de sua análise enfatizar que o grau de militância dos carismáticos fosse baixo, duas tendências despontavam. A primeira tendência estaria relacionada com certa vocação para o engajamento social, presente já nos primórdios do movimento no Brasil. Isso deveu-se ao fato de que o autor encontrara, entre seus entrevistados, $17,8 \%$ dos membros e $28,6 \%$ dos dirigentes com engajamento social declarado. Se, por um lado, isso o levou a afirmar que a RCC "[...] não é um estímulo ao engajamento social de seus participantes", por outro lado, também o levou a aceitar a ideia de que é entre os dirigentes que "[...] o engajamento já se faz notar" (Ribeiro de Oliveira, 1978, p. 38). Além disso, o autor (Ribeiro de Oliveira, 1978, p. 36-37) acentuava a existência de um imaginário socialmente engajado entre os carismáticos, por conta tanto da existência de um "estreito vínculo entre experiência espiritual e o engajamento social", expressado nas "Orientações Teológicas e Pastorais..."2,

2 As "Orientaçôes Teológicas e Pastorais para a Renovação Carismática Católica” a que Pedro Ribeiro de Oliveira faz menção se conformam como o resultado das primeiras reflexôes estimuladas pelo episcopado católico sobre a questão dos carismáticos, realizadas

Debates do NER, Porto Alegre, ano I6, N. 27, P. I99-232, JAN./Jun. 2015 
quanto da existência de casos em que haveria “[...] uma preocupação maior com a sociedade na qual [o carismático] está inserido, e, assim, uma atuação no sentido de torná-la melhor", a partir do amadurecimento espiritual adquirido no meio. A segunda tendência pode ser encontrada em uma entrevista que Ribeiro de Oliveira (1978) cita, apontando para a necessidade de amadurecimento enquanto condição de possibilidade para um maior engajamento social entre os carismáticos. A ideia era de que

[...] o movimento ainda é recente no Brasil e ainda conta com pouco apoio do episcopado, condiçóes [que] dificultam bastante o amadurecimento dos seus membros, e por isso a passagem da renovação apenas no âmbito interior à renovação da Igreja e da sociedade torna-se mais demorada (Ribeiro de Oliveira, 1978, p. 37-38).

O amadurecimento, então, segundo o entrevistado, dependeria de tempo e de apoio, para que tornasse possível o desenvolvimento pleno do engajamento social dos carismáticos, que, na fala citada por Ribeiro de Oliveira, encontrava-se em processo de germinação.

Depois dessas referências que nos apresentam o levantamento bibliográfico de Hunt e a pesquisa de Ribeiro de Oliveira, a primeira olhando para as décadas de 1970/80 e a segunda situada nas décadas de 1970/80, foi apenas a partir da segunda metade da década de 1990 e depois, na década de 2000, que outra pequena quantidade de textos sobre carismáticos e política apareceu. Nesse contexto, as ações dos carismáticos na cena política foram avaliadas tanto por uma perspectiva brasileira, com os trabalhos de Reginaldo Prandi e Fernando Valentin (1998), Julia Miranda (1999), Brenda Carranza (2000),

nos ano de 1974-75. Segundo Oro e Alves (2013, p. 124), este documento foi publicado em 1975, após “[...] iniciativa do cardeal Leon Joseph Suenens que, em maio de 1974, reuniu em Malines, Bélgica, uma equipe internacional de teólogos e dirigentes leigos para tratar do tema”. Para estes autores, "[...] o documento [...] quis ser, como seu título indica, um guia de orientação teológica e pastoral, tanto para os membros da RCC quanto para a Igreja em geral" (Oro; Alves, 2013, p. 124).

Debates do NER, Porto Alegre, ANo i6, N. 27, P. I99-232, JAn./Jun. 2015 
Marjo de Theije (2002), Emerson Silveira (2008), Rodrigo Portella (2011), Carlos Procópio (2012a; 2012b) e Péricles Andrade (2014), quanto por uma perspectiva euro-estadunidense, com os trabalhos de Christine Pina (1997; 1999) e Hunt (2008). Estas últimas, produzidas em contextos acadêmicos distintos, guardam certa correspondência com as primeiras, uma vez que as polaridades da interpretação no contexto brasileiro sobre aquilo que os carismáticos fazem na política acabam encontrando um ponto de equilíbrio ao serem contrastados com aquela produção estrangeira.

Para o caso brasileiro, a presença dos carismáticos na política tem se mostrado um ponto controverso no interior do pensamento das ciências sociais dedicada ao tema. Por um lado, acredita-se que os carismáticos privilegiam uma agenda política mais conservadora, na medida em que procuram tocar em temas ligados à evangelização e à moralização do Estado e da sociedade, posicionando-se de modo corporativo na esfera política (Prandi; Valentin, 1998; Carranza, 2000; Portella, 2011; Andrade, 2014). Por outro lado, passa-se a considerar que a experiência individual dos carismáticos, projetada para fora de si em direção ao outro, motivaria muitos carismáticos para a inclinação política, com posições variadas (Miranda, 1999; Theije, 2002; Silveira, 2008; Procópio, 2012a).

A vantagem dos trabalhos de Prandi e Valentin (1998), Carranza (2000), Portella (2011) e Andrade (2014) está em poder apreender um projeto político carismático claro e bem definido. Não se pode negar a existência desse projeto político carismático que, muitas vezes, pode esbarrar em uma dimensão estritamente corporativista. Entretanto, a prática política dos carismáticos não se resume a isso, pois, se por um lado a religião penetra na política, por outro, a política penetra na religião. Nesse sentido, se há corporativismo, também pode haver cooperativismo, e se há particularismo, também pode haver pluralismo. Apesar de não se poder negar o posicionamento conservador por parte da Renovação Carismática em matéria de política, cujas preocupações são moralizantes e corporativas, é importante frisar a ideia de que os carismáticos são tão reformadores quanto o são outros movimentos sociais, sobretudo quando esses temas moralizantes se inclinam

Debates do NER, Porto Alegre, ano I6, N. 27, P. I99-232, JAn./Jun. 2015 
para a injustiça social e a corrupção, que têm, de alguma forma, um lugar cativo dentro da esfera política. Se os carismáticos desejam uma reforma do estado e da sociedade, sem dúvida seu universo moral pesa, seja pelo lado do valor da família, seja pelo lado da caridade. Contudo, a caridade que os carismáticos procuram fazer pode ser pensada como articulada com o "dever do estado", e sua defesa da família com temas como liberdade, direito à vida e autonomia. Que suas bases de atuação são as religiosas, isto não se pode negligenciar, mas elas podem ser conjugadas com o civismo, o republicanismo, entre outras formas de síntese política consideradas mais progressistas.

Já a vantagem dos trabalhos de Miranda (1999), Theije (2002), Silveira (2008) e Procópio (2012a) está em poder perceber os arranjos e as mutações que ocorrem quando da inserção política dos carismáticos. Movidos pela variedade das ações que os carismáticos desenvolvem, esses autores têm sinalizado para a composição de uma esfera política como porosa na canalização das demandas e na inserção de agentes religiosos nessa esfera. Entretanto, o signo que rege essas perspectivas é o da conversão automática de valores religiosos em valores políticos, fabricando um comportamento político aureolado por uma simbologia religiosa. A passagem de uma esfera para outra, no entanto, não é automática. A porosidade das fronteiras não reduz os relevos a serem contornados. A relação entre religião e política é dependente de continuidades e justificações, que vai além de uma simples troca de signos. Envolvem processos permanentes de mediações, conversões, sistematizações, anulaçõos, entre outras.

Na medida em que são aproximados, esses dois conjuntos de reflexões sinalizam para o caráter ambíguo da ação política dos carismáticos, caráter esse que Pina (1997; 1999) e Hunt (2008) parecem indicar em seus textos. Sem apontarem para uma posição conclusiva em relação ao sentido da atividade política entre carismáticos católicos, estes autores esforçam-se em equilibrar analiticamente as dinâmicas que atravessam esse segmento, permitindo ver as tensōes que performam suas ações no âmbito político. Se, por um lado, há forças que tendem a levar os carismáticos para mais perto 
dos valores focalizados pela Igreja Católica, e aqui estarão em contato tanto com ideias conservadoras quanto progressistas e cuja opção será difícil de decidir, por outro lado, e uma vez contaminado pelas ideias com as quais manteve contato quando das suas vivências no seio da igreja romana, os carismáticos não só procurarão buscar correspondências com forças políticas que lhes sejam mais satisfatórias e em consonância com sua experiência na religião, quanto também serão impactados pelas ideologias que estas forças alheias ao religioso acabam imprimindo sobre eles.

Para o caso francês, Pina (1997, p. 113) procura pensar como é que “[...] uma experiência espiritual forte (o encontro com Deus que chega a marcar a vida do sujeito entre o antes e o depois) poderia reconstruir a imagem da sociedade e da política". Nesse sentido, ela tenta marcar que os tipos de inserção social e política dos carismáticos vão ser relativos às experiências grupais e/ou comunitárias que cada fiel vai desenvolver. Comparando as comunidades Chemin Neuf e Béatitudes, a autora vai traçando diferenças entre elas, no que tange ao modo como suas visões de mundo imprimem seus estilos e comportamentos sociais e políticos, mesmo que compartilhando uma mesma cosmogonia ${ }^{3}$.

Para Pina (1997), o membro da comunidade Chemin Neuf pensa a sua experiência religiosa como algo adquirido de modo contínuo, como parte de uma busca religiosa permanente, dando um caráter lógico para sua presença na comunidade. Isto produziria “[...] uma noção de roteamento e itinerário que insiste sobre a necessidade do reencontro com Deus para garantir uma consistência para a vida como um todo, evitando a separação entre a existência e o mundo como coisas distintas" (Pina, 1997, p. 117). Essa comunidade aproximar-se-ia de um tipo de conduta que articularia

\footnotetext{
3 Neste artigo será observada apenas a visão da autora sobre a comunidade Chemin Neuf, cuja participação política é incisiva. A comunidade Béatitudes coloca-se em contraposição à participação política e a explicação desse comportamento não contribui de forma propositiva para este trabalho, pois mostra outra faceta do movimento carismático, que aqui não é objeto de exploração.
}

Debates do NER, Porto Alegre, ano I6, N. 27, P. I99-232, JAn./Jun. 2015 
o laicismo com o ascetismo. Laicistas porque "[...] buscam no mundo as condiçôes de realização da mensagem evangélica, pela e graças à comunidade” e ascéticos porque procuram, através de seu comportamento e maneira de ser “[...] demonstrar que são um instrumento de Deus" (Pina, 1997, p. 118). Nessa medida, o engajamento político e a atividade social são compreendidos "[...] como uma entre outras que se aproxima da experiência religiosa dos envolvidos com a comunidade" (Pina, 1997, p. 123), já que ambas fariam parte do mundo em que o membro da comunidade coabita.

Essa conduta mostra-se mais clara quando Pina (1999) encontra uma inclinação desse tipo de comunidade para problemas da cidade, na medida em que se viam como responsáveis pelo seu desenvolvimento, bem como mostravam-se dispostos a compartilhar os problemas dela com seus contemporâneos não comunitários. Comportando-se como cidadãos interessados, não viam contradição entre envolvimento na Igreja Católica e a ação na sociedade, tendo

[...] um interesse na gestão dos assuntos públicos, demonstrando principalmente seus membros mais velhos um envolvimento mais explícito com a cidade, a familiaridade com os números atuais da política francesa, o desejo de verem políticos debaterem com líderes religiosos, além de terem um bom conhecimento sobre o que se passava na cena política no país (Pina, 1999, p. 94-95).

Assim, o Chemin Neuf prova executar uma negociação "[...] mais marcada pelo diálogo e à gestão aberta da esfera pública” (Pina, 1999, p. 96).

Hunt (2008), para o caso americano, sugere, por sua vez, que "[...] os católicos carismáticos são puxados em direções diferentes a respeito de opiniōes e alianças políticas, estando sujeitos a influências de dinâmicas contrastantes e lealdades concorrentes, dificultando conclusões" (Hunt, 2008, p. 27). Nesse sentido, a tese de Hunt é que o catolicismo carismático tanto pode se aproximar das posições políticas da própria hierarquia católica, por um lado, quanto assimilar, passiva ou ativamente, elementos políticos locais, por outro. Dessa forma, o catolicismo carismático não seria, substancial- 
mente, nem tradicionalista nem progressista, nem substancialmente liberal ou conservador, podendo suas orientações se aproximar ora da direita ora da esquerda política (Hunt, 2008). De acordo com o autor, há uma inclinação liberal nos primórdios do movimento nos Estados Unidos, na medida em que procuravam marcar uma renovação de elementos tradicionais pela experiência individual, ligada à realização de si (Hunt, 2008). Contudo, conquanto passam a se voltar de forma crítica para uma sociedade taxada por eles como permissiva, os carismáticos acabam por se inclinar para uma dimensão política fundamentalista e conservadora, na qual defendem uma "regeneração moral", em contraste com o comportamento disseminado pela cultura considerada como secular, ligada ao materialismo e à promiscuidade (Hunt, 2008).

Entretanto, Hunt (2008) esclarece que, mesmo quando ocorre uma tendência mais para a direita no meio carismático, um grande embaraço se dá entre eles quando o assunto é pena de morte, ensino do criacionismo nas escolas, bem estar social das mulheres, desenvolvimento de armas nucleares, postura antigay. Estas posições são defendidas por aquilo que se define por Nova Direita Cristã, que congrega a maioria dos grupos "spirit-filled" protestantes, de quem o catolicismo carismático, pertencente à mesma linhagem revivalista, na leitura do autor, aproximar-se-ia muito relativamente. Segundo Hunt (2008, p. 42), nesse cenário, os carismáticos “[...] provaram ser mais liberais em suas atitudes”. Além disso, os carismáticos procuram marcar que "[...] o catolicismo ensina sobre o respeito da dignidade inerente a cada pessoa, insistindo que nada na bíblia ou na doutrina católica poderia ser usado para justificar atitudes e comportamentos preconceituosos ou discriminatórios" (Hunt, 2008, p. 43).

A partir de Pina e Hunt, podemos não só aproximar as linhas que atravessam o movimento carismático sinalizados de maneira diversa entre os cientistas sociais da religião brasileiros, mas apostar num movimento multiposicional que atravessa a ação política dos carismáticos, fruto dos vínculos sociais e políticos estabelecidos pelos próprios grupos e pelas comunidades. Antes que uma visão monolítica sobre aquilo que os caris-

Debates do NER, Porto Alegre, ano I6, N. 27, P. I99-232, JAn./Jun. 2015 
máticos fazem e pensam sobre a política, são as complexidades das tramas nas quais estão envolvidos aquilo que será analisado. Aquele movimento multiposicional reflete-se nas candidaturas que recebem apoio de grupos e comunidades, estabelecendo um tensionado processo que vai depender da maneira como é articulado o grau do vínculo que possuem os candidatos com grupos e comunidades, do tipo de visão política daqueles que coabitam grupos e comunidades e que endereçam questões e demandas aos candidatos apoiados e das necessidades que os candidatos apoiados têm de ampliar seus vínculos para que possam galgar êxito eleitoral, em que sofrerão pressões similares àquelas que encontram e/ou podem encontrar na relação com seus vínculos originais.

\section{O MOVIMENTO MULTIPOSICIONAL}

Os dilemas com que os candidatos, inclusive os carismáticos, defrontam-se na época das eleições vão conduzi-los a um processo de fabricação de estratégias e comportamentos visando a conseguir adesão - palavra-chave para aqueles que desejam ter sucesso em suas empreitadas eleitorais (Palmeira; Heredia, 2010). Essa adesão muitas vezes se dá para além dos vínculos originais de cada personagem envolvido. Nesse contexto, a busca pela aceitação será um bem perseguido firmemente. Isso leva os candidatos a negociarem dentro de um cenário amplo que envolve a formação de opinião, conquista de voto e veiculação de informação. $\mathrm{O}$ círculo vicioso que isso faz pode levar a excessos e decorrentes frustrações, na medida em que os candidatos podem se afastar de suas propostas iniciais no afã de estender suas redes para além das originais. Nesse sentido, vão conviver com uma tensão permanente e, portanto, tecer correlações, que se não as mais produtivas, que sejam as menos desastrosas nos espaços em que vão ser estimulados a adentrar.

Quando aponto para a situação multiposicional desse processo, quero sublinhar que a maioria das candidaturas ultrapassa seus vínculos originais e estendem sua ação para outros coletivos, como forma de ampliar suas inserções na esfera política e aumentar suas chances de êxito. Esse conceito 
multiposicional foi elaborado por Odaci Coradini (1999; 2009) para o estudo das condições de ampliação e sustentação de candidaturas políticas quando do processo eleitoral, cuja extensão se faz pertinente para candidaturas religiosas (Procópio, 2012a; 2014). Para Coradini (1999, p. 14), “[...] a quase totalidade de candidatos lança mão de mais uma [base] de recursos e esferas sociais, de acordo com o seu trajeto e inserção social e política e as afinidades possíveis". Essa situação multiposicional pressupõe princípios de legitimação que "[...] remetem tanto às diferentes esferas sociais às quais esses candidatos se vinculam de algum modo, no atual ponto de suas trajetórias, como também àquelas com as quais mantiveram algum vínculo em alguma fase do passado e que podem ser reatualizadas" (Coradini, 1999, p. 14). Nessa medida, Coradini nota que esses vínculos vão desde uma ótica corporativa, quando os candidatos são apresentados como representantes legítimos de certos setores sociais, até uma ótica meritocrática, quando envolve a questão do saber fazer e da competência. Tal situação envolveria uma definição polifônica da função de representação que, na política, “[...] significa tanto o direito de falar em nome dos outros como o de demonstrar através da própria pessoa aqueles em nome dos quais se fala" (Coradini, 1999, p. 11).

Entretanto, vale marcar que, apesar de se constituírem sobre uma situação multiposicional, a conduta desenvolvida por candidatos como os ligados ao catolicismo carismático não é um projeto totalmente desarticulado, que assimila bases indiscriminadamente ${ }^{4}$. Nas eleições, paradoxalmente, mais pode ser menos, já que o excesso de bandeiras pode acabar implicando uma lealdade duradoura com nenhuma. Mesmo que as diferentes bases acionadas não possuam afinidades entre si, é preciso assegurar que não há entre elas secessão. Não há problema em representar vários segmentos, desde que as

4 Coradini não havia se preocupado em marcar, dentro de sua perspectiva, o fato de que as adesões sofrem com limites, já que não é possível assimilar todas as frentes que se queira sem levar prejuízo. Isto será o responsável pelo contorno da própria ação política como um ato performativo. Tentei levar isso em conta na argumentação desenvolvida na sequência.

Debates do NER, Porto Alegre, ano I6, N. 27, P. I99-232, JAn./Jun. 2015 
ideias que se quer referendar não sejam simetricamente excludentes, e que, pelo menos, mantenham algum grau de continuidade. Tal continuidade, argumentativa ou simbólica, converte as esferas dissonantes em conjuntos harmônicos, na qual a assimilação das necessidades das bases, ou os apoios e as estratégias de campanha consigam ecoar como uma só voz, coerente em princípios e orientaçôes diante daqueles a quem se apresentam.

Olhando para as eleiçóes proporcionais de 2014, focalizando nas candidaturas ligadas ao catolicismo carismático, podemos encontrar esse movimento multiposicional. Se por um lado os candidatos ligados a esse movimento católico terão que assimilar aquilo que suas bases demandam, por outro lado também procurarão ampliar suas redes de apoios e estratégias de campanha, conquanto isso seja necessário para garantir algum sucesso político. Nesse caso, quando combinaçôes e ajustes fizerem-se necessários, por conta da ampliação dos vínculos (religiosos) originais em direção a outros tipos de vínculos, tentar-se-á um equilíbrio dando forma e materialidade política àquilo que os candidatos desejam e/ou são pressionados a fazer.

\section{AS ELEIÇŌES DE 2014}

Nas eleições proporcionais de 2014, não foram poucos os candidatos que de algum modo se diziam vinculados ao catolicismo carismático ou eram por esse movimento propalados como pessoas políticas de sua confiança 5 .

5 Desde o final dos anos de 1980, registra-se a participação política de carismáticos nas eleições proporcionais. A dissertação de Vinícius Reis (2011) traz um importante levantamento desta presença até as eleições de 2010, especialmente nos cargos de deputado estadual e federal. Não se trata apenas de um levantamento da participação dos carismáticos nas eleições e dos candidatos a partir daí eleitos, mas também de um grande esforço em levantar sua atividade parlamentar. Entretanto, é lamentável que tal contingente de dados explorado por Reis seja por ele obscurecida por uma necessidade de marcar uma presença religiosa intransigente na esfera política, negligenciando aberturas e fechamentos entre religião e política que tal presença política estaria indicando quando se observa de perto seus dados.

Debates do NER, Porto Alegre, ANo I6, N. 27, P. I99-232, JAN./JUn. 2015 
Candidatos já conhecidos do público carismático, como Maria Teresa Lara, Eros Biondini e Odair Cunha, em Minas Gerais, Padre Afonso Lobato, Salvador Zimbaldi e Rafael Zimbaldi, em São Paulo, lançaram-se mais uma vez a candidatos a uma vaga ou para a Câmara dos Deputados ou para as Assembleias Legislativas. Outros candidatos, como o caso de Flavinho da Canção Nova, em São Paulo, lançaram-se pela primeira vez a uma vaga parlamentar. A análise que se segue se concentra em analisar duas destas candidaturas ${ }^{6}$. A primeira é a do Padre Afonso, do Partido Verde (PV), eleito por três vezes consecutivas para Assembleia Legislativa de São Paulo. A segunda é a de Flavinho, neófito em disputa eleitoral, que concorreu por uma vaga no Congresso Nacional pelo Partido Socialista Brasileiro (PSB) ${ }^{7}$.

\section{A CANDIDATURA DE PADRE AFONSO}

Padre Afonso, 54 anos, disputava sua quarta eleição consecutiva, estando filiado ao mesmo partido, o PV, desde 2002, quando elegeu-se pela primeira vez para deputado estadual. Conforme sua página no Facebook na época da eleição, sua vocação religiosa foi despertada na adolescência, quando dirigiu-se para o Seminário em uma cidade de Santa Catarina (1978), a fim

6 A escolha destes candidatos deve-se a dois fatores: $1^{\circ}$ ) o vínculo que estes possuíam com a região do Vale do Paraíba/SP, onde realizei trabalho de campo entre julho e outubro de 2014; 20) o vínculo que estabeleciam com o catolicismo carismático, especialmente com a Comunidade Canção Nova, sediada em Cachoeira Paulista, no Vale do Paraíba.

7 Os dados foram coletados através de trabalho de campo na região do Vale do Paraíba e em pesquisa na internet, especialmente as páginas oficiais dos candidatos. Compuseram o banco de dados analisado: panfletos coletados nas ruas e na internet; download de vídeos nas páginas dos candidatos; anotações e gravações que foram feitas nas atividades de campanha que acompanhei, como caminhadas, reuniōes, comícios e debates. Agradeço aos alunos do IFSP Camilla Pessonia, Marcus Maello, Priscilla Ferraz e Wesley Moreira pelo auxílio na coleta de dados na internet e organização do banco de dados.

Debates do NER, Porto Alegre, ano I6, N. 27, P. I99-232, JAn./Jun. 2015 
de ordenar-se padre, fato que se concretizaria aos seus 28 anos. Sua atuação sacerdotal inicia-se em Taubaté (SP), onde se dedicou, a partir da ordenação, a cuidar da população carente do local, o que o levou a fundar a Obra Social Bom Pastor, naquela cidade do Vale do Paraíba/SP. Em 1998, conforme sua página no Facebook, ele se forma em Direito, e a partir daí começa a dirigir a Pastoral Carcerária. De acordo com esta fonte, "[...] essas experiências com as obras sociais levaram Padre Afonso a procurar novos caminhos para que pudesse ajudar melhor a comunidade de Taubaté e da região", o que o teria conduzido a tentar uma ação política como deputado estadual, a partir das eleiçôes proporcionais de 2002 e cujo sucesso do intento possibilitou suas reeleições em 2006 e 2010.

Em 2014, Padre Afonso procurou apresentar um amplo material de campanha, com tons de verde, que faziam alusão à sua pertença partidária, distribuído pelas ruas das cidades do Vale do Paraíba, onde procurava salientar seus feitos ao longo das suas legislaturas, seja para a região de uma forma geral, seja para a cidade onde estava sendo distribuído seu material de divulgação. Neste último caso, era estampado no cabeçalho "vote em quem trabalha pela sua cidade", tendo abaixo desta frase o nome da cidade a que se referiria o panfleto em letras garrafais. Ao lado das conquistas que a cidade teve a partir da ação do candidato, o material divulgado nas ruas apontava metas para um próximo mandato, estas, por sua vez, mais gerais e sem menção direta à cidade em particular. Entre a fotografia do candidato e das informações sobre a qual cargo estava concorrendo e do número que deveria ser digitado caso o eleitor optasse pelo apoio a sua candidatura, o selo de ficha limpa ficava estampado. No rodapé da página, do lado onde figurava a imagem do candidato, um coração verde destacava-se, tendo grafado a seu lado a frase "Trabalho em defesa da Vida".

$\mathrm{Na}$ internet, um conjunto de vídeos foram produzidos e depois veiculados através de canais como o Youtube, muitos destes possíveis de serem acessados e compartilhados a partir da própria página no Facebook do candidato. Seguindo um padrão de apresentação, estes programas, com duração entre dois e três minutos, procuravam alterar durante a fala do 
candidato, closes frontais e laterais da imagem deste narrando seus feitos, sempre vestindo trajes comuns, com imagens das obras que realizou na região. Quando o assunto do programa restringia-se a esclarecimentos sobre determinadas posições políticas que deseja defender, as imagens de seus feitos davam lugar aos closes frontais e laterais do candidato falando. Por um lado, esses programas procuravam rememorar o eleitor das açōes desenvolvidas pelo Padre Afonso na região do Vale do Paraíba como um todo, sendo muitas dessas ações enfatizadas em detalhes no material de campanha citado anteriormente. Por outro lado, procurava posicionar o candidato para o eleitor em relação a temas controversos, inerentes à ideologia e/ou prática majoritária de seu partido, mas que eram vistos com maus olhos pela Igreja Católica e uma parte do eleitorado ligado a esta instituição religiosa, especialmente os alinhados com o catolicismo carismático.

Olhando para a imagem que desejava promover a partir de seus panfletos, Padre Afonso deixava entrever pelo menos dois movimentos. $\mathrm{O}$ primeiro movimento está ligado às obras que disse ter promovido ou que pensava em promover nas cidades da região e que privilegiam setores do catolicismo ou valorizava sua ação como membro dessa instituição. Nesse quesito, o candidato procurou marcar sua atividade em favor de entidades desvinculadas da Igreja Católica, como as Santas Casas e APAEs, mas também junto a entidades subsidiadas por aquela instituição religiosa, como casas de recuperação de usuários de drogas, asilos e fanfarras da região, para quem afirmava ter direcionado recursos financeiros e equipamentos. $\mathrm{O}$ segundo movimento relacionava-se às obras viabilizadas ou desejadas para a região que tratavam de contemplar a população como um todo. Nesse sentido, as obras realizadas ou em vias de realização versavam sobre canalização de córregos, compensação por serviços ambientais, agricultura familiar, tratamento de água e esgoto, defesa do Rio Paraíba do Sul, recuperação de sua bacia hidrográfica e posição contrária à sua transposição, verbas para infraestrutura das cidades (ambulâncias, iluminação pública, áreas de lazer etc.), recuperação e/ou duplicação de estradas de rodagem intermunicipais, serviços médicos de nível local e regional (pron-

Debates do NER, Porto Alegre, ano I6, N. 27, P. I99-232, JAn./Jun. 2015 
tos-socorros e hospitais), isenção de impostos para autoescolas, projeto de implementação de um trem regional e consolidação de cidades da região como Estância Turística.

Estes dois movimentos permitem ver como o religioso e o político se fazem presentes e atravessam a candidatura de Padre Afonso: o primeiro levando o candidato a atuar direta ou indiretamente a favor da causa católica, por conta de sua pertença institucional (benefícios diretos) ou por conta do seu chamado vocacional (benefícios indiretos); o segundo levando o candidato a ter que canalizar temas e demandas inerentes à ideologia de seu partido (causa ambiental) e da ação política em moldes de brokerage ${ }^{8}$ (concessões e benefícios). É exemplo de benefício direto à causa católica a viabilização de cerca de dois milhōes de reais para a Fazenda Esperança, em Guaratinguetál SP, entidade que cuida de jovens usuários de drogas. Esta proposição do candidato é bastante pontual e focaliza uma ação específica do catolicismo da região, já que a referida comunidade faz um trabalho que é ao mesmo tempo social e religioso. Indiretamente relacionado à causa católica, mas fortemente atrelada à prática vocacional do candidato, está a canalização de verbas para as Santas Casas de Misericórdia, cujos recursos transferidos ultrapassam um milhão de reais, conforme ressaltados no conjunto de panfletos distribuídos na região. $\mathrm{O}$ apoio a instituições que cuidam da saúde das pessoas se coloca aqui como um compromisso do próprio sacerdócio, que é também um compromisso com a vida das pessoas, justificando o mote da ação de Padre Afonso. A pertença partidária e uma tentativa de diálogo com essa pertença aparecem na disposição do candidato em atuar junto à questão ambiental da região. A valorização do Rio Paraíba do Sul e a defesa

8 De acordo com Mische (2008), uma relação de brokerage é geralmente descrita como o envolvimento entre setores que, através de determinadas situações, criam formas de colaboração e aliança. Nesse léxico, o broker é o sujeito que recebe um ganho pessoal por conta da sua capacidade de ligar setores que estariam estruturalmente desconectados. A discussão sobre o funcionamento desta prática de brokerage é muito bem analisada em Coradini (1999).

Debates do NER, Porto Alegre, ANo I6, N. 27, P. I99-232, JAN./JUn. 2015 
deste como sua bandeira na área ambiental provam a pertença partidária, o que também ocorre com a viabilização de obras pontuais de saneamento articuladas ao tratamento de esgoto ou a recuperação de regiōes assoreadas, cujo investimento disponibilizado chegava à ordem dos quatrocentos milhões de reais. Por fim, concessões específicas para as cidades não deixam de se fazer presentes, e muitos foram os recursos disponibilizados para este fim, como os dois milhôes destinados para a infraestrutura turística de uma das cidades da região ou açôes mais pontuais, como áreas de lazer e compra de veículos, com valores destinados que oscilavam entre cem mil a trezentos mil reais por cada serviço.

Já os programas (vídeos) veiculados na internet, ajudam a compreender um pouco mais profundamente as conexões que Padre Afonso fazia entre religião e política. Por um lado, alguns desses programas procuravam salientar as obras viabilizadas pelo candidato para a região, por outro lado, ressaltavam temas controversos de sua candidatura, como a questão do aborto e da liberação de drogas, bandeiras inerentes ao seu partido, e da participação de padres na política.

Em relação ao primeiro conjunto de programas, muito do que Padre Afonso procurou salientar se encontrava pontualmente descrito em seus panfletos. Entretanto, aqui carregavam uma retórica mais acentuada, fazendo um apelo para necessidades reconhecidas que não tiveram esforços poupados para sua consecução por parte do candidato, seja a partir de uma ação direta, na elaboração de projetos e emendas parlamentares, seja indiretamente, agindo como um mediador junto ao poder executivo do estado. Dos vídeos coletados, os temas apresentados neste quesito versavam sobre: implementação do hospital regional no Vale Histórico/SP'; apoio a entidades sociais para tratamento de dependentes químicos; reformulação e implementação de um novo sistema carcerário; políticas públicas para a redução da criminalidade entre jovens e adolescentes; defesa do Rio Paraíba e de sua bacia hidrográfica;

9 O Vale Histórico está situado dentro do Vale do Paraíba e é composto por seis municípios: Arapeí, Areias, Bananal, Queluz, São José do Barreiro e Silveiras.

Debates do NER, Porto Alegre, ano I6, N. 27, P. I99-232, JAn./Jun. 2015 
criação de novas ETECs e FATECs ${ }^{10}$; apoio a Santas Casas; duplicação de rodovias; preservação e produção da água; implementação do trem regional. O que é digno de nota em relação a esses programas é a ausência de uma referência direta à religião na formatação do discurso. As obras eram colocadas como voltadas para o favorecimento do bem comum, minorando as dificuldades das pessoas e dando a elas oportunidades de viverem melhor as suas vidas. É o esforço político de Padre Afonso que é ressaltado, cuja ação é fruto de demandas da sociedade da qual ele se elegeu representante e cuja função quer continuar exercendo. Ao que parece, o candidato quer se manter sintonizado de maneira incisiva com a região do Vale do Paraíba. Mas, se por um lado levanta bandeiras de demandas imediatas como saúde, educação e transporte, reforçando o caráter de brokerage de sua legislatura, por outro lado, atravessa por essas outras bandeiras como o meio ambiente e assistência social, sinalizando para um comprometimento mais ideológico de seu mandato ${ }^{11}$.

Já em relação ao segundo conjunto de programas, o que Padre Afonso desejou veicular era sua contraposição a temas que, no interior de seu partido, gozavam de significativa aceitação. Por outro lado, também procurou justificar como legítima sua ação política, apesar de padre da Igreja Católica, contrapondo-se a críticas que viam assimetria entre estas duas funções.

No primeiro caso, lamentava a posição que possuíam alguns de seus correligionários de partido, que defendiam o aborto, bandeira que se colocava como incongruentes com sua formação religiosa, pois, uma vez que

${ }^{10}$ ETECs são Escolas Técnicas Estaduais, enquanto FATECs são Faculdades de Tecnologia. Oferecem formação técnica e tecnológica gratuita em várias cidades do estado de São Paulo.

${ }^{11}$ Se se quer ver uma aproximação à dimensão religiosa na candidatura de Padre Afonso, esta só pode ser vista na medida em que se cotejam os dados referentes a este comprometimento ideológico, especialmente na área assistencial. Não exploro esta aproximação neste texto por cautela e falta de dados que possam ajudar na justificação de tal assertiva. Tenho procurado evitar generalizações apressadas, procurando mais ver os sentidos localizados das ações dos candidatos.

Debates do NER, Porto Alegre, ANo I6, N. 27, P. I99-232, JAN./Jun. 2015 
era padre, acreditava que a vida deveria ser defendida desde sua concepção até sua morte natural. Por isso salientava que não só se contrapunha a tal prática como lutava pela defesa da vida como um todo, que incluía a vida humana, animais, rios e florestas, apesar da primeira receber prioridade, na acepção do candidato. A mesma contraposição a temas de aceitação correntes no interior de seu partido se dava na discussão sobre a legalização das drogas. Padre Afonso procura marcar que é contra a criminalização do usuário, que deve ser tratado em clínicas especiais. Mas contrapóem-se à legalização, apontando para o mal que as drogas fazem para as pessoas, suas famílias e a sociedade na qual estão inseridos. Sua ação junto a clínicas de tratamento de usuários, ajudando com emendas parlamentares e destinação de recursos públicos, prova sua preocupação com o problema. Contudo, não descarta a necessidade da discussão do tema, que deveria ser feito em momento oportuno, não ao calor do momento, em que temas como esse ganham uma dimensão eleitoreira e acabam sendo canalizados para a desqualificação de candidaturas, como estaria ocorrendo com a sua, que é criticada pelo fato de estar ligada a um partido reconhecido como defensor de bandeiras como as citadas, colocando em xeque a idoneidade de sua posição política e religiosa.

O que vale enfatizar neste ponto é que a posição de seu partido em relação a temas como aborto e legalização de drogas é apresentada como encontrando resistência intrapartidária em posições como a do candidato. Isso relativizaria a identificação do Partido Verde como um partido monolítico no que tange a bandeiras como aborto e legalização das drogas, já que há divergência interna sobre eles. Nesse sentido, se o peso da religião se faz presente na posição de Padre Afonso em relação a esses temas no interior de seu partido, também é relevante a defesa da vida dentro de um amplo espectro natural-cultural, realocando a posição do candidato para um polo mais político. Se a religião pesa na hora do candidato se colocar diante de temas como os citados, levando-o a se posicionar de acordo com aquilo que é propalado no interior de sua instituição religiosa, esse peso religioso é relativizado quando a discussão é colocada dentro de um plano

Debates do NER, Porto Alegre, ano I6, N. 27, P. I99-232, JAn./Jun. 2015 
mais amplo, em que a vida ganha uma dimensão universalista e passível de ser confundida com a própria causa partidária, que tem a vida como mote de sua ação.

No segundo caso, Padre Afonso procurava responder a questão referente ao lugar de padres na política, lugar que ele coloca como muitas vezes contestado quando desdobrado na ação partidária. O candidato coloca sua prática como que em consonância com sua pertença institucional e seu sacerdócio, uma vez que a política era colocada tanto como espaço de ação do cristão por papas como Francisco e João Paulo II, já que é vista como lugar por onde a caridade poderia ser praticada, quanto espaço por onde a fé se personificaria em obras, conquanto desdobrada em ação junto aos mais necessitados. Padre Afonso acredita que a função do padre está diretamente relacionada à vida do fiel. Se a vida deste não se resume à missa, a do padre também não pode se resumir a esta. Defende que a ação pela melhoria de vida das pessoas transcende o espaço religioso, uma vez que precisam suprir necessidades básicas que só podem ser conquistadas junto ao espaço político, o que justifica a ação dos padres junto a este espaço, uma vez que o caminhar do padre é com aqueles pelos quais é pastor. Aponta ainda que o problema da política muito se deve ao problema dos políticos, que muitas vezes não cumprem bem a função para a qual foram escolhidos, levando a um descrédito da população em relação à política. Padre Afonso defende que a política é boa em si mesma, porque é orientada sempre para o fazimento do bem, que só não consegue atingir seus objetivos quando bloqueada pela ação de políticos desinteressados com o bem comum, que devem, por sua vez, ser impedidos pela ação do voto em candidatos compromissados com a função primeira da política.

Neste programa veiculado pela candidatura de Padre Afonso, a relação entre política e religião é simétrica. A religião, a partir de um compromisso institucional ou vocacional, encontra na política uma forma de ação. Seria pela política que a caridade poderia ser canalizada de maneira incisiva, convertendo fé em obras. Mas é também pela política que o padre continuaria sua ação pastoral, de atendimento pleno daqueles sobre os quais

Debates do NER, Porto Alegre, ANo I6, N. 27, P. I99-232, JAN./Jun. 2015 
detém responsabilidade, fazendo da vida religiosa e da vida civil uma só. A política, por sua vez, encontraria na forma como a religião a define, uma maneira de se desprender de um espectro pragmático e utilitário imputado pelos políticos, que a desvirtualizam na medida em que fazem dela abuso. Nesse sentido, fazer a política boa demandaria ser um bom político, que só consegue ser filtrado quando se faz uso correto do voto, que só atinge seus objetivos quando orientado por tal definição de política.

\section{A CANDIDATURA DE FLAVINHO}

Flavinho, 42 anos, lançava-se pela primeira vez a um cargo político. Estando filiado ao PSB, ele pleiteava uma vaga na Câmara dos Deputados. Natural da região (Guaratinguetá), ele iniciou, segundo material divulgado em seu site à época do processo eleitoral, sua atividade junto a Igreja Católica aos quinze anos, quando fez parte do ministério de música do Grupo Pastoral da Juventude da Paróquia São Pedro Apóstolo, na sua cidade natal. Aos 23 anos, junto com sua esposa, ingressou como membro consagrado da Comunidade Canção Nova em Cachoeira Paulista ${ }^{12}$, condição que abandona em $2009^{13}$. Sua presença junto a este segmento católico é fortemente marcada

${ }^{12}$ Para uma discussão sobre a categoria "membro consagrado" e o lugar que ocupa na Canção Nova, ver a tese de Eliane Oliveira (2011).

${ }^{13}$ Flavinho disponibilizou uma cópia da carta de desligamento da Canção Nova no seu site pessoal. Chama atenção que a escolha dele e de sua família pelo desligamento tem como justificativa a necessidade de darem continuidade a um chamamento profético, apreendido no interior da comunidade: "Depois de um discernimento feito com muita cautela e verdade ao longo de três anos, decidimos dar este passo. Muitas razões e direcionamentos de Deus nos impeliram a dar mais esse passo de fé em nossa busca constante por realizar sempre em nossa vida e de nossa família a Santa Vontade de Deus. Peço perdão por não haver comunicado antes esta decisão. Tomamos com dor no coraçãa, mas o chamado de Deus é sempre maior. Na Canção Nova fomos formados como Família Consagrada a Deus, amadurecemos como Missionários, aprendemos a ser profetas que anunciam a segunda vinda do Senhor, estivemos por quinze anos na Escola Profética Jonas Abib. Eu e minha

Debates do NER, Porto Alegre, ano I6, N. 27, P. I99-232, JAn./Jun. 2015 
pela atividade musical, tendo tido inúmeras músicas gravadas por padres de renome como Fábio de Mello e Marcelo Rossi. Gozando de grande fama junto ao catolicismo em geral, mais particularmente entre os carismáticos, Flavinho traz em sua bagagem o fato de ter evangelizado em mais de vinte países, escrito livros traduzidos em algumas línguas e ser nome constante nas missas do Padre Jonas Abib na condição de animador, na comunidade Canção Nova ou fora dela. Muitas dessas funções não foram abandonadas no momento em que conduzia sua campanha eleitoral.

Sua entrada na política, entretanto, conforme salienta as informações obtidas em seu site de campanha, não foi fruto de uma decisão sem premeditaçôes. De acordo com esta fonte "Flavinho tem acompanhado e apoiado o movimento político dentro da Igreja Católica há pelo menos 15 anos e agora lança sua candidatura a Deputado Federal por São Paulo com o intuito de lutar no Congresso Nacional para que os valores da família, da vida, da ética e da moral sejam respeitados, valorizados e preservados em nosso país". Por mais que o Espírito Santo possa ter tido algum papel nessa decisão, esta inclinação de Flavinho para a política é bastante programática ${ }^{14}$. Desse modo, procura focalizar um projeto que move sua candidatura, que denominou "eu acredito na força do bem". Tal projeto tem como mote "animar, encorajar e motivar a ação efetiva de boas pessoas em nosso Estado e mostrar que é possível transformar a política e a sociedade do nosso país com coerência, decência, seriedade e amor ao próximo, especialmente os mais pobres, sofridos e marginalizados". Desse modo, "Flavinho deseja trabalhar com todas as suas forças para instaurar o Reino da Justiça e da Paz onde a corrupção, o egoísmo e a indiferença darão lugar a justiça, a partilha e a solidariedade".

família estamos em um tempo novo muito fecundo! Nos sentimos como uma planta que necessitava sair do viveiro para ser transplantada e crescer dando assim muitos frutos".

${ }^{14} \mathrm{O}$ peso do Espírito Santo na motivação de candidaturas ligadas ao catolicismo carismático foi explorado em Procópio (2014).

Debates do NER, Porto Alegre, ANo I6, N. 27, P. I99-232, JAN./Jun. 2015 
Durante as eleições de 2014, a tentativa de emplacar tal projeto pode ser vista em dois momentos: a participação de Flavinho em uma sabatina com outros candidatos a deputado federal da região promovida pela AESI (Associação para o Ensino Social da Igreja Católica), na Faculdade Católica de São José dos Campos/SP; material de campanha coletado em seu site contendo as missóes que o candidato desejava emplacar junto à esfera política, caso eleito.

A sabatina que reuniu os candidatos a deputado federal da região não tinha como meta confrontar os candidatos entre si, mas apresentá -los à comunidade local e endereçá-los alguma pergunta através de um sorteio. Aos vários candidatos presentes no evento, foi dada a oportunidade de três falas: a primeira, em que o candidato se apresentava; a segunda, quando sorteava-se uma pergunta que este candidato deveria responder; e a terceira, na qual o candidato poderia fazer suas considerações finais. $\mathrm{O}$ tempo total para cada candidato, somado os três momentos, contabilizava dez minutos.

Flavinho procurou salientar, em sua primeira fala, que a política, enquanto "arte do bem comum", estava atrelada à atividade de transformação do mundo. Tal atividade estaria no cerne do próprio cristianismo, já que para ele a ação de Jesus Cristo nada mais era do que política. Daí saía sua própria motivação para participação na esfera política, segundo Flavinho. Além disso, nesse momento de sua fala, o candidato procurou enfatizar que pretendia pautar sua atuação na defesa dos valores cristãos e no compromisso com a vida, eixo central de sua candidatura. Acredita que existia uma agenda política a ser implementada e que tinha como meta a regulamentação do aborto, o que para ele teria como consequência a destruição da família e a destruição do país. Por isso, sua insistência em se colocar como paladino da família e da vida, chegando a afirmar que não haveria reforma política eficaz sem a valorização destas esferas. $\mathrm{Na}$ sequência, recusa a ideologia partidária em benefício da ideologia evangélica, afirmando que fazia da política a extensão de uma ação evangelizadora no mundo. Para Flavinho, filiado a um partido com alcunha socialista, o

Debates do NER, Porto Alegre, ano I6, N. 27, P. I99-232, JAn./Jun. 2015 
socialismo e comunismo seriam inaceitáveis, como também seria para ele o capitalismo na sua acepção "selvagem". Por fim, o candidato procurou marcar também que sua atuação política estaria em consonância tanto com o episcopado (pois dizia ter recebido a benção de bispos da região para ser candidato da diocese) quanto com o papa, que apoiaria a ação política dos católicos, desde que servissem ao bem comum. Na sua segunda fala durante a sabatina, Flavinho respondeu uma pergunta sobre quais meios deveriam ser tomados para a ampliação da participação democrática. Respondeu que era preciso voltar o apreço pela política e pelos políticos, menosprezados pela população e subvalorizados porque a referência das pessoas sobre a política são os políticos que não agem em conformidade com sua função de atender o bem comum. Para o candidato, era preciso limpar a imagem dos políticos, invertendo a lógica de menosprezo, através da ação dos políticos compromissados com a decência e coerência e transparência, reavivando, com isso, a esperança das pessoas na política. Nas suas considerações finais, Flavinho procurou ressaltar os pilares do seu projeto "eu acredito na força do bem”. Estes seriam três: político, social e evangelizador. Sem esclarecer o funcionamento de cada um desses pilares, disse privilegiar sua coerência de vida, o que o levaria a "não compactuar nem com o socialismo/comunismo nem com o capitalismo selvagem", acreditando no "evangelho que gera aquilo que é necessário para todos".

Olhando para seu material de campanha, percebe-se a intenção de Flavinho em marcar aquilo que denominou de missóes, que, olhadas atentamente, permitem uma compreensão mais ampla daquilo que o candidato quer fazer na política. Elas podem ser agrupadas em duas direções: relacionadas a questões ético-religiosas (família; defesa da vida); relacionadas a questôes ético-políticas (combate à corrupção; mandato transparente).

Nas questôes ético-religiosas, Flavinho acredita que "a família sempre foi, é e sempre será a base da sociedade, sendo ela por excelência um lugar privilegiado de formação e construção do caráter, da ética, da moral e dos bons costumes na vida de cada um daqueles que a compõe”. Nesse sentido,

Debates do NER, Porto Alegre, ANo I6, N. 27, P. I99-232, JAN./JUn. 2015 
sugere que esta deve ser a força necessária para que a sociedade subsista enquanto algo equilibrado. Sem ela, apontava o candidato, "estaremos abrindo as portas para um tempo de descalabros morais e sociais ainda maiores dos que aqueles que já estamos vendo e presenciando". Como mote de ação política, sinaliza que procurará defender a família de ataques e investidas vindas de políticos, grupos ou leis. A defesa da vida não foge a esse tom mais conservador. Convicto de que o destino da vida é monopólio divino, assume que não se pode deixar de fazer frente às empreitadas políticas e financeiras de partidos e pessoas que se colocam na dianteira do combate contra a vida humana. Entretanto, se por um lado a vida humana a ser defendida é aquela dos fetos e embriōes, por outro lado inclui os idosos, que são "impossibilitados de ter uma passagem digna para eternidade esperando o tempo natural para sua partida", bem como "aqueles que estão a margem da sociedade sem acesso a saúde de qualidade, sem educação, sem trabalho, sem moradia e sem ter o básico para viver”. Diante disso, Flavinho procura se comprometer em levantar bandeiras que não são aquelas propaladas por partidos, mas por aquilo que é condizente com o evangelho, este sim sua bandeira e ideologia, conforme consta em seu material de campanha.

Nas questôes ético-políticas, o que é colocado em jogo, quando fala-se em combate à corrupção, é uma crença na sua existência difusa na sociedade brasileira, que atingiu não só os políticos, mas também as "estruturas políticas, empresariais, econômicas e até mesmo religiosas". Tal mal tem como consequência a miséria de milhôes de pessoas, por causa do "total abandono e escassez do básico que um ser humano necessita para ter uma vida digna”. Uma vez detectado o mal, ele precisa ser combatido, e Flavinho não deixa dúvidas sobre como isso deve ser consumado. Ele acha que a corrupção deve ser combatida com "decência, coerência, ética e também com leis e punições exemplares, fazendo com que corruptos e corrompidos paguem centavo por centavo os danos causados aos cofres públicos, à nação e aos mais pobres que, infelizmente, são sempre os mais atingidos e prejudicados com os atos corruptos". Diz estar fazendo eco aos apelos que dizia ter visto

Debates do NER, Porto Alegre, ano I6, N. 27, P. I99-232, JAn./Jun. 2015 
nos acontecimentos de julho de $2013^{15}$, onde a corrupção havia sido eleita como causa principal das reivindicações, sendo a extinção desse mal uma de suas metas.

Ao falar de transparência, Flavinho mantém a toada crítica. Para ele, muitos políticos chegam à política com uma "terrível deficiência de caráter", dificultando o atendimento das demandas coletivas. Para o candidato, estes maus políticos pensam que o cargo é monopólio deles e não daqueles que os elegeram, deixando de usar com exatidão a função que lhes foi concebida. Desejando fazer diferente, Flavinho pensa que "os que são eleitos precisam ter a decência, o respeito e o carinho para com aqueles que o elegeram sendo transparentes e coerentes em todas as suas ações no exercício do seu mandato". Para tanto, pensa que a transparência é essencial na condução de um cargo político, uma vez que dá aos eleitores a garantia de que compromissos fundamentais serão honrados, especialmente aqueles atrelados ao bem comum. Antes que um favor, para Flavinho, a transparência é "uma obrigação de um homem público que deseja ser coerente e honesto em suas ações".

As posições tomadas pelo candidato durante a sabatina e em seu material de campanha, por mais esparsas que elas estejam, permitem situá-las dentro de pelo menos quatro movimentos. No primeiro é notória a necessidade de se colocar como um defensor de bandeiras morais pautadas na religião, bandeiras morais que devem ser protegidas, porque são elas que alicerçariam a sociedade. Essa sociedade estaria fadada ao esfacelamento na medida em que uma agenda contrária a essas bandeiras fosse instaurada. No segundo movimento, o que temos é a legitimação da candidatura a partir da afirmação

${ }^{15}$ Os acontecimentos de junho-julho de 2013 foram acionados por várias candidaturas em 2014, como movimento propagador de reformas e mudanças no país. Há inúmeras controvérsias sobre os sentidos daqueles protestos, podendo ser encontrados nas ciências sociais brasileiras variados esforços de explicação. Daqueles estudos a que tive acesso, a interpretação de Angela Alonso e Ann Mische (2014) é a que traz consigo uma maior preocupação analítica, bastante distanciada das inspiradas pelo calor do momento.

Debates do NER, Porto Alegre, Ano i6, N. 27, P. I99-232, JAN./Jun. 2015 
de que ela está avalizada pelo episcopado da região e pelo argumento papal, dando plausibilidade para os motes da candidatura, na medida em que ela passa a ser vista como que em consonância com a Igreja Católica e os valores propalados por esta instituição, ou pelo menos ditos pelo candidato que ela apoia. No terceiro movimento, emerge um argumento próximo a uma terceira via, entre capitalismo e socialismo, apresentando a candidatura como que a serviço de um bem comum, que não se deixar levar por interesses político-partidários ${ }^{16}$. No quarto movimento, o que emerge é uma toada crítica à ação dos políticos, distanciada da ética e da transparência, que colocaria Flavinho, por optar por uma posição contrária a uma usual prática dos políticos, em continuidade com ventos que estariam por clamar modificações radicais na estrutura da política.

Esses quatro movimentos atravessam o que o candidato elege como foco de sua ação, que é a vida das pessoas e a defesa desta em sua integralidade, gerando um ciclo de açóes que envolvem a pessoa e o meio que ela habita. O cuidado com os outros ajuda também a entender a necessidade que o candidato vê em reformar os políticos, cuja ação deve ser orientada para fins coletivos, não para interesses individuais ou corporativos. Há um mote central nesta ação, o bem comum, que encontra em parte uma correspondência. Não se pode deixar de mencioná-lo, no evangelho propalado pelo catolicismo, pelo menos isso é que o candidato procurava acentuar. Além disso, nesse movimento, o candidato passa por uma teoria política que valoriza a representação como algo que deve ser voltado para $\mathrm{o}$ atendimento de todos ${ }^{17}$. O fato de ter sido escolhido por uma fração da

\footnotetext{
${ }^{16}$ Não há nenhuma novidade neste discurso. No interior do pensamento católico, não foram raros os momentos em que os políticos ligados a tal pensamento procuraram marcar e optar por uma terceira via, apesar das controvérsias que isso gerava no momento de sua aplicação. Para os debates sobre a terceira via política entre católicos na América Latina, ver Mainwaring e Scully (2010).

${ }^{17}$ Quando falo de teoria política, estou levando em conta sua existência por um ponto de vista nativo, da mesma forma que Goldman (2006).
}

Debates do NER, Porto Alegre, ano I6, N. 27, P. I99-232, JAn./Jun. 2015 
sociedade não garante ao eleito o direito de legislar só por aqueles pelos quais foi eleito, mas imprime sobre este o dever de atuar em benefício de toda sociedade ${ }^{18}$.

\section{CONSIDERAÇÕES FINAIS}

À guisa de conclusão, cabe ressaltar alguns pontos inerentes às candidaturas de Padre Afonso e Flavinho, que reforçam o movimento multiposicional, salientado em tópico específico deste artigo.

Padre Afonso tem mais experiência em eleições e acumula três mandatos consecutivos, o que lhe dá mais condições de trabalhar em várias frentes de modo mais concreto e incisivo. Não há dificuldade em imaginarmos que procura pontuar suas açóes junto a cada uma das localidades que quer continuar representando na Assembleia Legislativa, salientando os aspectos infraestruturais que procurou privilegiar. Atendimentos isolados das necessidades de cada cidade são conjugados com atendimentos visando à integração intermunicipal. Se, por um lado, muito do que diz ter feito encontra espaço junto à retórica do partido ao qual estava filiado, fortemente ligado à causa ambiental, por outro lado, outras açóes encontram espaço junto à sua atuação vocacional religiosa, marcado pela caridade e pelo atendimento dos anseios da comunidade pela qual diz pastorear. Estas duas frentes prioritárias não eliminam a inserção de novas frentes a serem trabalhadas, como é o caso da ação do candidato pela diminuição dos impostos de autoescolas. Quando controvérsias aparecem dentro do polo partidário ou religioso, as saídas encontradas muito mais ampliam o plano de ação de Padre Afonso do que

${ }^{18}$ Esta assertiva, embutida na campanha de Flavinho, traz consigo uma série de paradoxos, como a de que bem comum ele está falando ou até que ponto ser representante eleito por uma parte garante, em nível parlamentar, a legitimidade de poder falar por todos. Entretanto, em nível de retórica, pelo menos na forma que Herzfeld lhe dá (2005), isso é uma questão menor, já que é o uso prático das formas políticas como as apresentadas por Flavinho que contam, mais que uma condição a priori dessas formas.

Debates do NER, Porto Alegre, Ano i6, N. 27, P. I99-232, JAN./Jun. 2015 
as diminui. A posição contrária à legalização das drogas não apenas coloca o candidato como um daqueles que se apresentam como voz divergente no interior de um partido cuja bandeira da legalização das drogas tem ampla aceitação, mas o coloca também em associação com setores que pensam na contramão da posição majoritária do partido do candidato. Já a posição em relação à participação de padres na política recoloca a função de sacerdote dentro de um espectro amplo de ação pastoral, que ao invés de se resumir à atividade paroquial relativa à missa e/ou atividades estritamente religiosas, se estende para outros ramos da vida onde o fiel se faz presente e anseia por atendimento. As esferas partidária e religiosa na candidatura de Padre Afonso encontram um ponto comum quando o tema da vida, o religioso, amplia-se para cuidado com o meio ambiente, o partidário, onde esta vida encontraria regozijo, criando uma ideia ampla de vida que pode circular por variados segmentos sociais e encontrar aí alguma simpatia ou simplesmente satisfazer sujeitos dentro das esferas religiosa e partidária que reclamam por concepções mais abstratas de definição política.

Flavinho tem menos caminhada na disputa política eleitoral, o que ajuda a compreender sua menor ênfase sobre propostas que poderíamos prontamente detectar como de brokerage. Sua opção é apresentar uma candidatura mais ideológica, enfatizando bandeiras morais, caritativas e políticas genéricas no afã de conquistar adesão. $\mathrm{O}$ movimento multiposicional, nesta candidatura, aparece justamente quando Flavinho se defronta com questôes de cunho político, que o obriga a ter que acionar uma teoria política que em nada aponta para um proselitismo perceptível em parte significativa de sua atividade de campanha, especialmente quando tratava de questôes que denominei de ético-religiosas. Uma acepção de representação política, como apontada no tópico específico neste artigo dedicada ao candidato, em nada lembra valores do catolicismo, apesar desses valores poderem ter passado por esse e educado a atenção de Flavinho sobre este aspecto da política. $\mathrm{Na}$ medida em que incorpora tal pensamento político, Flavinho amplia sua presença política, estando propenso a se conectar com outros segmentos políticos, alheios, em princípio, ao universo católico e carismático. A recusa

Debates do NER, Porto Alegre, ano I6, N. 27, P. I99-232, JAn./Jun. 2015 
que este candidato faz das ideologias partidárias também o coloca dentro de um movimento multiposicional. Mesmo que seja um lugar comum no catolicismo optar por uma terceira via entre capitalismo e socialismo, ao fazer isso, Flavinho abre-se para grandes nichos na população brasileira que estão muito pouco inclinados a optar por uma das duas organizaçóes político-econômicas citadas ${ }^{19}$. O processo é idêntico quando o que está em jogo é o apontamento de que o problema da política são os políticos ou que a corrupção deve ser combatida ou que o mandato deve ser transparente. O espectro de tal percepção extrapola e muito os limites de sua pertença religiosa inicial, tornando possível transladar o candidato para além de seus vínculos (religiosos) originais.

Esta assertiva justifica-se inclusive em momentos na condução da campanha do candidato em que o peso da religião está mais marcado. A defesa da família e da vida vai ganhando uma forma universalizante o suficiente para colocar Flavinho em consonância com segmentos políticos que defendem direitos fundamentais do ser humano como moradia, alimentação, trabalho, educação etc. Esta maneira de ampliar o sentido daqueles valores religiosos não vai ter apenas efeito fora do campo religioso, mas dentro deste também, já que muitos dos frequentadores do universo católico e carismático vão ter uma posição política correspondente com valores encontrados na sociedade em geral ${ }^{20}$. Entretanto, não se pode eliminar a possibilidade de que acionar este tipo de retórica serve para Flavinho tergiversar sobre os pontos família e vida, dando para estes uma face mais palatável no campo da política do que aquela propalada no religioso. Porém,

${ }^{19}$ Conforme pesquisa divulgada no dia 08/09/2014 pelo Instituto Datafolha, 21\% do eleitorado brasileiro declarava ter posição política de "centro", 1 ponto percentual a menos do que o encontrado no ano anterior. Disponível em: <http://datafolha. folha.uol.com.br/eleicoes/2014/09/1512693-direita-supera-esquerda-no-brasil.shtml>. Acesso em: 1 dez. 2014.

${ }^{20}$ Procópio (2014) apresenta um conjunto de declarações que ajudam na confirmação desta prática no interior do catolicismo carismático.

Debates do NER, Porto Alegre, ano i6, N. 27, P. I99-232, JAN./Jun. 2015 
na medida em que ampliam as bases de seu argumento, eles passam a fazer parte de seu discurso e vão precisar ser trabalhados, correndo o risco de se performarem como vazios e diminuírem a adesão, sem a qual a eleição se tornaria mais difícil.

Por fim, reitero que o que quis ao longo deste trabalho foi demonstrar como a relação entre catolicismo carismático e política se constitui dentro de um movimento ao qual denominei de multiposicional, pelo menos se levadas em conta as campanhas políticas dos dois candidatos do Vale do Paraíba. Tal opção deu-se por conta do interesse em ver de perto o modo como esses candidatos fabricam suas práticas e ações políticas em face de suas opções religiosas. Quanto mais próximo do universo político e religioso, maior é a complexidade apresentada. Nesse sentido, o rastreamento das articulaçóes efetuadas na prática dos candidatos Padre Afonso e Flavinho converte-se em ferramenta eficaz que mostra que é por uma leitura horizontal do envolvimento do catolicismo carismático com a política, especialmente durante o período eleitoral, que tal envolvimento pode ser melhor compreendido.

\section{REFERÊNCIAS}

ALONSO, Angela; MISCHE, Ann. Changing repertoires and partisan ambivalence in the new Brazilian protest. In: SEMINARIO DE SOCIOLOGIA, POLÍTICA E HISTÓRIA, LAPS/USP, São Paulo, 2014.

ANDRADE, Péricles. Acorda, Canção Nova: conservadores católicos e eleiçôes presidenciais em 2010. In: CONGRESSO INTERNACIONAL EM CIÊNCIAS DA RELIGIÃO, PUC GOIÁS, 7., Goiânia, 2014.

BAPTISTA, Saulo. Pentecostais e neopentecostais na politica brasileira: um estudo sobre cultura política, Estado e atores coletivos religiosos no Brasil. São Paulo: Annablume, 2009.

CARRANZA, Brenda, Renovação carismática católica: origens, mudança e tendências. Aparecida: Santuário, 2000.

Debates do NER, Porto Alegre, ano I6, N. 27, P. I99-232, JAn./Jun. 2015 
CORADINI, Odaci. Em nome de quem? Rio de Janeiro: Ed. RelumeDumará, 1999.

Origens Sociais, mediação e processo eleitoral num município de imigração italiana. In: BARREIRA, Irlys; PALMEIRA, Moacir (Org.). Candidatos e Candidaturas: enredos de campanha eleitoral no Brasil. São Paulo: Annablume, 2009.

GOLDMAN, Márcio. Como funciona a democracia: uma teoria etnográfica da política. Rio de Janeiro: 7 Letras, 2006.

HERZFELD, Michael. Intimidade Cultural. Lisboa: Ed. 70, 2005.

HUNT, Stephen. Betwixt and between: the political orientations of roman catholic neo-Pentecostals. Politics and Religions, n. 2, Cambridge, UK, p. 27-51, 2008.

MAINWARING, Scott. Igreja Católica e Politica no Brasil. São Paulo: Editora Brasiliense, 1989.

MAINWARING, Scott; SCULLY, Timothy. La democracia cristiana en América Latina. México, D.F.: Fondo de Cultura Económica, 2010.

MIRANDA, Julia. Carisma, sociedade e politica. Rio de Janeiro: Relume Dumará, 1999.

MISCHE, Ann. Partisan Publics: Communication and Contention across Brazilian Youth Activist Networks. Princeton: Princeton University Press, 2008.

OLIVEIRA, Eliane. Sinfonia Inacabada: segredo, imaginação e a Comunidade de Vida Canção Nova. 2008. Tese (Doutorado em Ciências Sociais, Agricultura e Desenvolvimento) - CPDA/UFRRJ, Rio de Janeiro, 2008.

ORO, Ari; ALVES, Daniel. Renovação Carismática Católica: movimento de superação da oposição entre catolicismo e pentecostalismo? Religião \& Sociedade, Rio de Janeiro, v. 33, p. 122-144, 2013. 
PALMEIRA, Moacir; HEREDIA, Beatriz. Politica Ambigua. Rio de Janeiro: Relume-Dumará, 2010.

PINA, Christine. Religion et politique dans le "Renouveau charismatiques": le cas de deux communautés françaises. Religiologiques, Montréal, n. 16, p. 113-133, 1997.

The City, the Countryside and Nature in the Discourse of Two Charismatic Revival Communities: Two Visions of Society and Politics? Social Compass, v. 46, n. 1, p. 85-99, 1999.

PORTELLA, Rodrigo. Renovação Carismática Católica: relaçôes, interferências e tensões. Atualidade Teológica, ano 15, n. 39, p. 644-657, 2011.

PRANDI, Reginaldo; VALENTIN, Fernando Farias. A renovação carismática e a política. In: PRANDI, Reginaldo. Um sopro do espirito. São Paulo: EdUSP, 1998. p. 171-118.

PRANDI, Reginaldo. Perto da magia e longe da política. In: PRANDI, Reginaldo; PIERUCCI, Antônio Flávio. A realidade social das religiōes no Brasil. São Paulo: HUCITEC, 1996.

PROCÓPIO, Carlos Eduardo Pinto. Religião e política: reflexões a partir do carismatismo católico. In: MELLO, Luiz et al. (Org.). Questôes de Sociologia: debates contemporâneos. Goiânia: Cânone Editorial, 2012a.

. Carismatismo Católico e Eleições no Brasil. Ciencias Sociales y Religión, Porto Alegre, v. 14, p. 79-99, 2012b.

Perto da Religião, Perto da Política: a participação do catolicismo carismático através da Instituição, Candidaturas e Mídia nas eleições de 2010. 2014. Tese (Doutorado em Ciências Sociais) - PPGCSO/UFJF, Juiz de Fora, 2014.

REIS, Marcos Vinícius de Freitas. Política e religiāo: o envolvimento dos católicos carismáticos na política brasileira. 2011. Dissertação (Mestrado em Ciência Política) - PPGCP/UFSCAR, São Carlos, 2011.

Debates do NER, Porto Alegre, ano I6, N. 27, P. I99-232, JAN./Jun. 2015 
RIBEIRO DE OLIVEIRA, Pedro. A RC como agremiação religiosa. In: RIBEIRO DE OLIVEIRA, Pedro et al. (Org.). Renovação Carismática Católica: uma análise sociológica, interpretaçōes teológicas. Petrópolis: Vozes, 1978.

SILVEIRA, Emerson José Sena da. 'Terços', 'santinhos' e versículos: a atual relação entre os carismáticos e a política. REVER, São Paulo, p. 54-74, 2008. THEIJE, Marjo de. Tudo que é de Deus é bom. Recife: Massangana, 2002.

Recebido em: 10/01/2015 Aprovado em: 08/03/2015 